\title{
Implementasi model pembelajaran aswaja untuk membentuk muslim berkarakter religius-nasionalis
}

\section{Alifudin Ikhsan ${ }^{1 \star}$, Faris Khoirul Anam², Yusuf Hanafi ${ }^{3}$, Abdul Adzim $^{4}$, Zahrotul Muzdalifah ${ }^{5}$}

${ }^{1}$ Universitas Negeri Malang/SMP Darul Faqih Malang, Indonesia, email: um.alifudin93@gmail.com

2Universitas Negeri Malang, Indonesia, email: faris.fs@um.ac.id

3Universitas Negeri Malang, Indonesia, email: yusuf.hanafi.fs@um.ac.id

${ }^{4}$ Universitas Negeri Malang, Indonesia, email: abdul.adzim.fs@um.ac.id

5 Universitas Negeri Malang, Indonesia, email: zahromuzdalifah@gmail.com

*Koresponden penulis

\section{Info Artikel}

Diajukan: 09 Mei 2021

Diterima: 03 Sept 2021

Diterbitkan: 13 Sept 2021

Keywords:

learning model; aswaja; character; religious;

nasionalism

Kata Kunci:

model pembelajaran; aswaja; karakter; religius; nasionalis

\section{Lisensi:}

cc-by-sa

\begin{abstract}
Through the implementation of the Aswaja learning model in schools, this community service aims to develop Muslims with religiousnationalist personalities. It was carried out in three phases of activities, namely education \& outreach, implementation \& strengthening and intensive mentoring from March to May 2021 at SMP Darul Faqih Indonesia, Malang Regency. The results of the activity assessment showed a change in Aswaja's attitudes and practices in fostering religious-nationalist values in students. This also has implications for strengthening religious moderation in the school environment. The results of the correlation test of students' attitudes and practices showed a score (R-square: P-value) of 0.126: 0.000, which indicates that this activity has a significant impact. The implementation of the Aswaja learning model is aimed at providing a balanced understanding of religion and nationalism. Strengthening the understanding of religious moderation with a nationalism - religious spirit will be an important ingredient in the development of peace culture educationbased schools in Indonesia.
\end{abstract}

\begin{abstract}
Abstrak
Pengabdian kepada masyarakat ini bertujuan untuk membentuk muslim berkarakter religious-nasionalis melalui implementasi model pembelajaran Aswaja di sekolah. Dilaksanakan dalam tiga fase kegiatan yaitu edukasi \& sosialisasi, implementasi \& penguatan dan pendampingan intensif sejak Maret hingga Mei 2021 di SMP Darul Faqih Indonesia Kabupaten Malang. Hasil penilaian kegiatan menunjukkan adanya perubahan sikap dan praktik Aswaja dalam menumbuhkan nilai-nilai religious-nasionalis pada siswa. Hal ini juga berimplikasi pada penguatan moderasi beragama di lingkungan sekolah. Hasil uji korelasi sikap dan praktik siswa menunjukkan skor (R-square : $P$-value) sebesar 0,126:0,000 yang menunjukkan bahwa kegiatan ini memiliki dampak yang signifikan. Implementasi model pembelajaran Aswaja ditujukan untuk memberikan pemahaman beragama dan nasionalisme kebangsaan yang seimbang. Penguatan pemahaman moderasi beragama dengan semangat nasionalisreligious akan menjadi bahan penting pengembangan sekolah berbasis peace culture education di Indonesia.
\end{abstract}




\section{PENDAHULUAN}

Ancaman radikalisme baik dalam pemikiran dan aksi makin meningkat (Ibrahim et al., 2017; Llorent-Bedmar et al., 2020). Dalam bidang teologi, terdapat beberapa hal yang berpotensi menjadi pemicu munculnya paham radikalisme-takfiri, seperti hakimiyah, al-wala wa al-bara, dan sebagainya (Aspihanto \& Muin, 2017). Radikalisme pun tidak hanya dalam bentuk aksi anarkisme tetapi juga bergeliat dalam pemikiran Islam itu sendiri (Rahardjo, 2017). Hal ini nampak dalam bidang amaliyah ubudiyah fikih, babon tasawwuf, hingga bidang teologis dan hukum Islam (Abdullah \& Yani, 2009). Kondisi ini tentu akan mempengaruhi gaya berpikir seseorang dalam kerangka kehidupan beragama yang toleran, inklusif dan moderat. Radikalisme pemikiran dan aksi keagamaan jauh lebih berbahaya jika tidak segera ditangani dengan serius (AlZewairi \& Naymat, 2017). Keterlibatan seluruh elemen dalam upaya pencegahan terhadap paham radikalisme sangat dibutuhkan (Aspihanto \& Muin, 2017; Llorent-Bedmar et al., 2020).

Dalam konteks ini, untuk mengeliminasi terbentuknya kelompok keagamaan yang eksklusif di sekolah, setiap lembaga perlu untuk mengambil peran baik sebagai fasilitator maupun pengambil kebijakan dalam membantu siswa menuju proses ke arah kedewasaan, saling menghargai perbedaan, seperti perbedaan etnis, budaya, dan agama (Abdullah \& Yani, 2009). Kepala Sekolah harus mampu bersikap lebih moderat dan mengambil kebijakan, memperkuat sosialisasi Pancasila, dan memperjelas pemahaman posisi keagamaan (Ibrahim et al., 2017). Secara halus dapat dilakukan lewat bahasabahasa agama yang relevan dan sosialisasi pandangan tentang adanya nilainilai afinitas antara agama dan Pancasila, dengan harapan dapat mengembalikan corak keagamaan yang jadi ciri khas beragama di Indonesia, yaitu moderat, inklusif, dan toleran (Rahardjo, 2017).

Mewujudkan sekolah berbasis religius-nasionalis merupakan sebuah tanggungjawab akademik bagi perguruan tinggi LPTK. Lembaga yang memiliki integritas dengan penanaman sikap nasionalisme dan memiliki semangat beragama yang moderat dapat menjadi sarana untuk mengamputasi paham radikal. Model pembelajaran berbasis Aswaja sejak awal 2000-an telah menjadi bagian dari moderasi beragama di Indonesia. Model pembelajaran ini menekankan pada sikap religius-nasionalis yang bertumpu pada pengembangan kehidupan beragama yang moderat. Kondisi ini cocok dengan kebutuhan mitra sasaran pengabdian kami yaitu SMP Darul Faqih Indonesia. Lembaga pendidikan Islam ini berada dalam wilayah multikultural beragama, dimana terdapat sekolah SMP berbasis Kristen, Hindu dan Katolik. Terletak di Desa Pandanlandung Kecamatan Wagir Kabupaten Malang, heterogenitas masyarakat menempatkan sekolah ini masuk dalam kategori rawan konflik sosial.

Implementasi model pembelajaran Aswaja untuk membentuk muslim berkarakter religius-nasionalis ini merupakan wujud pelaksanaan hasil penelitian yang telah dilakukan sejak 2019 lalu. Model pembelajaran ini terlahir dari maraknya kasus radikalisme atas nama agama yang terjadi di Indonesia. Berbagai pihak menganggap bahwa kekerasan atas nama agama oleh siswa 
SMP sebenarnya diakibatkan karena eksrimnya pemahaman guru dalam menyampaikan Pendidikan Agama Islam di sekolah. Padahal Islam menekankan moderatisme, inklusivitas, dan toleransi yang termaktub dalam AlQuran (Hanafi \& Ikhsan, 2019; Ikhsan, 2017a, 2017b), seperti perlindungan hak asasi manusia, kebebasan beragama, kesetaraan dan peluang yang setara untuk hak asasi manusia dalam masyarakat sipil (Yeşilova, 2010). UNESCO (UNESCO, 1995) mendefinisikan toleransi sebagai kebajikan yang memungkinkan perdamaian, berkontribusi pada penggantian budaya perang dengan budaya perdamaian.

\section{METODE PELAKSANAAN}

Untuk menjawab permasalahan mitra di atas, tim ini merumuskan sebuah kegiatan untuk mengimplementasikan model pembelajaran Aswaja dalam rangka memutus mata rantai radikalisme paham keagamaan di sekolah. Program kemitraan masyarakat ini dilaksanakan di SMP Darul Faqih Indonesia Desa Pandanlandung Kecamatan Wagir Kabupaten Malang. Adapun sasaran kegiatan yaitu siswa kelas VII dan VIII sejumlah 89 orang. Pada situasi pandemi Covid-19, pelaksanaan pengabdian ini telah dikonsultasikan kepada pemangku jabatan setempat dalam hal ini ketua SR-33 Wagir, ketua MKKS dan Polsek Wagir selaku penanggungjawab Satgas Covid-19 di wilayah tersebut. Pengabdian ini dilakukan dengan menerapkan protokol kesehatan yang ketat. Pengabdian masyarakat ini dilaksanakan Maret hingga Mei 2021.

Pengabdian dilakukan dengan 3 fase yaitu fase pertama, melakukan edukasi pemahaman toleransi dan semangat moderasi beragama terhadap siswa untuk memperoleh pemahaman yang utuh. Fase ini dilaksanakan dengan menggunakan model diskusi dan seminar. Fase kedua, melakukan pembekalan dan penguatan topik nasionalisme untuk menanamkan sikap patriotisme dan bela negara. Pada fase ini, tim bekerjasama dengan UPT Pusat Pengkajian Pancasila Universitas Negeri Malang untuk memberikan wawasan kebangsaan dengan teknik ketangkasan dan diskusi kebangsaan. Dan fase ketiga, memberikan pendampingan terhadap siswa selama selama 3 bulan untuk menerapkan model pembelajaran Aswaja di sekolah. Tim mengintegrasikan pembelajaran Pendidikan Agama Islam (PAI) dengan mata pelajaran Pendidikan Pancasila dan Kewarganegaraan (PPKn) guna mendapatkan hasil yang maksimal dalam membentuk karakter muslim religiusnasionalis. Selama masa pendampingan ini, tim juga melakukan pemantauan terhadap aktivitas keagamaan yang diselenggarakan sekolah. 


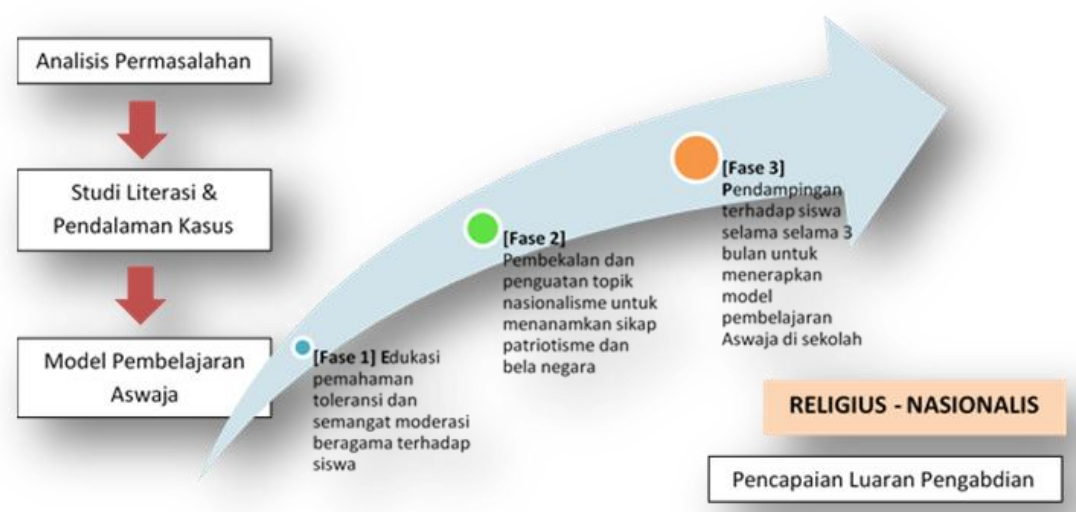

Gambar 1. Diagram alur pengabdian

Untuk mengukur seberapa berhasil program pengabdian masyarakat ini dilaksanakan, maka tim pengabdian Universitas Negeri Malang melakukan penilaian dengan cara mengukur indeks skor pretest dan posttest. Instrumen yang dikembangkan didasarkan pada pengetahuan, sikap dan praktik pembelajaran Aswaja dalam berkegiatan. Adapun analisis yang digunakan adalah perbandingan skor. Respon partisipan yang menunjukkan pengetahuan, sikap dan praktik dijelaskan dengan frekuensi dan persentase. Untuk menguji perbedaan skor sikap dan praktik berdasarkan karakteristik demografis, kami menggunakan independen sampel t-test dan analisis varian satu arah (ANOVA).

\section{HASIL DAN PEMBAHASAN}

Pengabdian kepada masyarakat merupakan salah satu tugas pendidik dalam tri dharma perguruan tinggi. Kegiatan pengabdian dilaksanakan dengan mempertimbangkan berbagai aspek yang ada khususnya permasalahan mitra sasaran. Sebagai bentuk tanggungjawab akademik terhadap lingkungan masyarakat, setiap peneliti harus mampu menyelesaikan masalah yang terjadi disekitarnya. Dalam konteks ini, permasalahan yang terjadi di tengah masyarakat khususnya SMP Darul Faqih Indonesia adalah tantangan moderasi Islam rahmatan lil 'alamin bagi generasi muda. Tak dapat dipungkiri, moderasi Islam menjadi bagian penting dalam perilaku beragama di Indonesia.

Moderasi Islam menjadi pembahasan serius satu dekade terakhir ini (Maskuri et al., 2020). Hal ini tidak terlepas dari meningkatnya intensitas ujaran kebencian, radikalisme dan eksrimisme (Ikhsan, 2019; Labiba, 2021). Pendidikan Islam sebagai benteng penangkal gerakan radikalisme dan ekstrimisme beragama justru memusatkan pikirannya pada kedalaman keilmuan ubudiyah. Setidaknya hal ini bisa tercermin dalam kurikulum pesantren yang selama ini lebih didominasi oleh kajian fikih, adapun kajian akidah dan peradaban Islam tampak kurang mendalam. Pengenalan apalagi penguasaan terhadap dunia pemikiran tasawuf atau sufi juga minim. Sementara 
penguasaan ilmu alat nahwu sharaf seakan menjadi tujuan utama, belum dimanfaatkan sepenuhnya untuk pendalaman ilmu-ilmu agama (Patriadi, 2015; Yaqin et al., 2020). Kurikulum pesantren yang dipadu dengan kurikulum nasional menjadi salah satu hal penting dalam pencegahan dan pengendalian paham radikal di Indonesia (Saleh et al., 2019).

Kegiatan penanaman nilai-nilai moderasi Islam sebenarnya telah dilakukan dengan berbagai cara diantaranya dengan memasukkannya pada mata pelajaran Pendidikan Agama Islam (PAI). Namun faktanya, PAI hanya berfokus pada transfer pengetahuan ubudiyyah-ilahiyyah tidak menyentuh faktor kemanusiaan. Hal ini dikhawatirkan menjadi bibit-bibit baru Gerakan ekstrimisme di dunia pendidikan. Oleh karena itu, kegiatan pengabdian kepada masyarakat yang dilakukan oleh tim LP2M Universitas Negeri Malang ini berfokus pada perwujudan muslim berkarakter religious-nasionalis melalui pengimplementasian model pembelajaran Ahlussunnah Wal Jamaah (Aswaja).

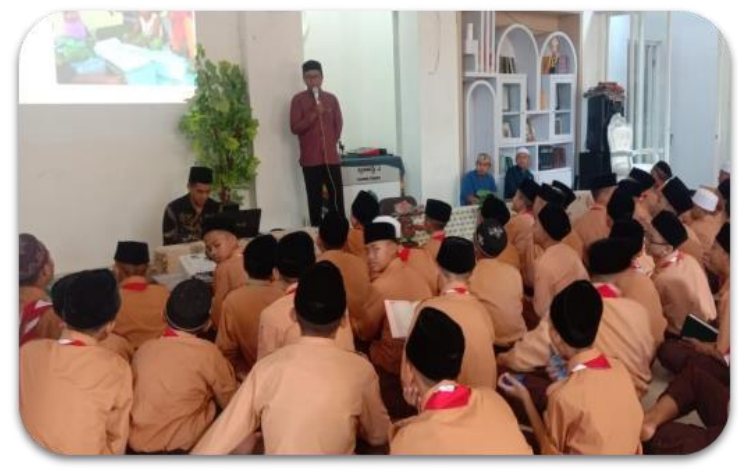

Gambar 2. Kegiatan edukasi dan sosialisasi Aswaja

Berbagai penelitian telah mengungkap bahwa Pendidikan Aswaja anNahdliyah memiliki kontribusi nyata dalam dalam upaya menangkal radikalisme beragama (Rifa'i et al., 2017; Saefudin \& Fatihah, 2020; Syarif, 2021). Pelajaran materi Aswaja dengan nilai-nilai moderat (tawassuth) yang terus ditanamkan kepada peserta didik dinilai mampu memberikan pemahaman agama yang lebih komperhensif dan lebih baik. Nilai moderatisme atau tawassuthiyah yang dikembangkan dalam pendidikan itu mampu mengkompromikan dua paham ekstrim, yaitu ekstrem kanan (radikal) dan ekstrem kiri (liberal) (Labiba, 2021; Wahyudin, 2017).

Di sisi lain, ancaman radikalisme baik dalam pemikiran dan aksi makin meningkat dewasa ini (Ikhsan, 2017a). Dalam bidang teologi, terdapat beberapa hal yang berpotensi menjadi pemicu munculnya paham radikalismetakfiri, semisal hakimiyah, al-wala wa al-bara, dan sebagainya. Dalam bidang fikih utamanya amaliah ubudiyah, di tengah umat Islam terdapat nalar hegemoni kebenaran dari kelompok Salafi-Wahabi, yang sejak era Muhammad bin Abdul Wahhab mengarusutamakan purifikasi agama di bawah slogan "kembali kepada al-Qur'an dan Sunnah". Sementara dalam bidang tasawuf, 
istilah 'babon' tasawuf itu sendiri juga telah banyak menuai kritik, dengan asumsi bahwa hal itu tidak didapati di zaman Nabi Muhammad SAW.

Di Indonesia, Ahlussunnah Wal-Jama'ah mengalami pelembagaan melalui organisasi Islam Nahdlatul Ulama. Paham ke-Aswaja-annya biasa disebut dengan istilah Aswaja an-Nahdliyah. Dengan adanya batasan kata "anNahdliyah", maka kontekstualisasi ajaran Aswaja pada implementasi model pembelajaran ini berada dalam lingkungan komunitas nahdliyin.

Pada fase pertama, kegiatan dilaksanakan dengan memberikan edukasi dan pemahaman toleransi beragama kepada para siswa. Kegiatan ini penting untuk dilakukan mengingat wilayah Kecamatan Wagir Kabupaten Malang memiliki beragam agama dan kepercayaan. Tujuan dari diadakannya kegiatan fase pertama ini adalah siswa mampu memahami makna keberagaman, toleran terhadap teman non muslim, mampu beradaptasi dengan lingkungan dan memberikan energi positif dalam bersosialisasi dengan teman-temannya. Model pembelajaran Aswaja yang diterapkan di jenjang SMP mampu memberikan penjelasan tentang bagaimana cara bersikap terhadap umat non muslim tanpa mengubah dan terpengaruh akidah Islam yang ada pada dirinya.

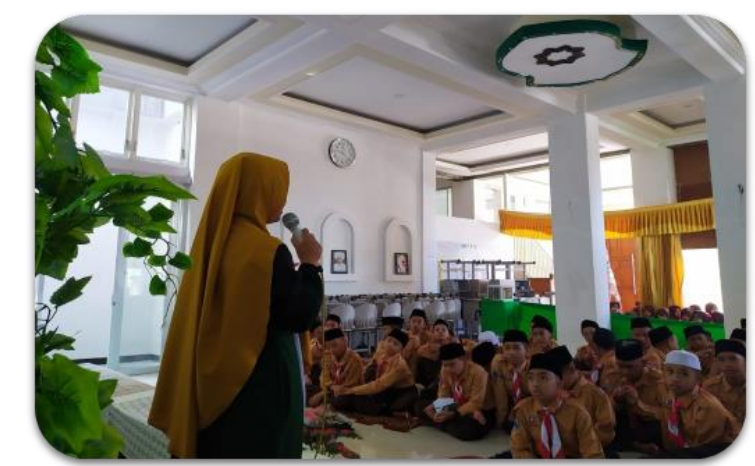

Gambar 3. Kegiatan implementasi model pembelajaran Aswaja

Dalam kegiatan fase ini, tim pengabdian melakukan pengukuran sikap siswa terhadap Aswaja sebagai bentuk penggalian informasi tentang sikap siswa SMP Darul Faqih Indonesia dalam mengimplementasikan model pembelajaran Aswaja. Berikut merupakan tabel respon terhadap instrument sikap beraswaja.

Tabel 1. Hasil respon sikap santri terhadap model pembelajaran Aswaja $(n=10)$

\begin{tabular}{|c|c|c|c|c|c|c|c|}
\hline \multirow[b]{2}{*}{ No. } & \multirow[b]{2}{*}{ Pernyataan } & \multicolumn{2}{|c|}{ Tidak Setuju } & \multicolumn{2}{|c|}{ Ragu-Ragu } & \multicolumn{2}{|c|}{ Setuju } \\
\hline & & $\begin{array}{c}\text { Freq } \\
(n)\end{array}$ & $\%$ & $\begin{array}{l}\text { Freq } \\
(n)\end{array}$ & $\%$ & $\begin{array}{l}\text { Freq } \\
(n)\end{array}$ & $\%$ \\
\hline $\mathrm{A} 1$ & $\begin{array}{l}\text { Mengamalkan amaliyah Aswaja an-Nahdliyah } \\
\text { dalam kehidupan sehari-hari dengan penuh } \\
\text { tanggungjawab }\end{array}$ & 1 & 1,12 & 6 & 6,74 & 82 & 92,13 \\
\hline $\mathrm{A} 2$ & $\begin{array}{l}\text { Menaati ajaran dan tradisi amaliyah Aswaja an- } \\
\text { Nahdliyah }\end{array}$ & 2 & 2,24 & 8 & 8,98 & 79 & 88,76 \\
\hline A3 & $\begin{array}{l}\text { Mengedepankan sikap toleran dalam menyikapi } \\
\text { tuduhan dan "serangan" kelompok di luar Aswaja } \\
\text { an-Nahdliyah seperti Wahabi, Syiah dan } \\
\text { kelompok liberal }\end{array}$ & 2 & 2,24 & 5 & 5,61 & 82 & 92,13 \\
\hline
\end{tabular}




\begin{tabular}{|c|c|c|c|c|c|c|c|}
\hline \multirow[b]{2}{*}{ No. } & \multirow[b]{2}{*}{ Pernyataan } & \multicolumn{2}{|c|}{ Tidak Setuju } & \multicolumn{2}{|c|}{ Ragu-Ragu } & \multicolumn{2}{|c|}{ Setuju } \\
\hline & & $\begin{array}{l}\text { Freq } \\
(n)\end{array}$ & $\%$ & $\begin{array}{l}\text { Freq } \\
(n)\end{array}$ & $\%$ & $\begin{array}{l}\text { Freq } \\
(n)\end{array}$ & $\%$ \\
\hline A4 & $\begin{array}{l}\text { Memberikan pemahaman kepada pihak yang } \\
\text { menganggap bid'ah amaliyah Aswaja an- } \\
\text { Nahdliyah seperti tahlilan, maulidan, manaqiban } \\
\text { dan lain sebagainya }\end{array}$ & 1 & 1,12 & 5 & 5,61 & 86 & 96,62 \\
\hline A5 & $\begin{array}{l}\text { Memberikan pemahaman kepada pihak yang } \\
\text { mengkiritik tradisi baik, tradisi Islami, atau } \\
\text { kearifan lokal yang tidak bertentangan dengan } \\
\text { ajaran Islam }\end{array}$ & 1 & 1,12 & 7 & 7,86 & 81 & 91,01 \\
\hline A6 & Menghormati pemeluk agama lain & 0 & 0,00 & 5 & 5,61 & 84 & 94,38 \\
\hline A7 & $\begin{array}{l}\text { Menghormati kelompok Islam di luar Aswaja an- } \\
\text { Nahdliyah }\end{array}$ & 1 & 1,12 & 3 & 3,37 & 85 & 95,50 \\
\hline A8 & $\begin{array}{l}\text { Memiliki sikap setia terhadap Pancasila, UUD } \\
\text { NRI Tahun } 1945 \text {, Bhinneka Tunggal Ika dan } \\
\text { Negara Kesatuan Republik Indonesia }\end{array}$ & 0 & 0,00 & 2 & 2,24 & 87 & 97,75 \\
\hline A9 & $\begin{array}{l}\text { Tidak mempermasalahkan sistem demokrasi } \\
\text { yang berlaku di Indonesia }\end{array}$ & 0 & 0,00 & 1 & 1,12 & 88 & 98,87 \\
\hline A10 & $\begin{array}{l}\text { Mendukung setiap kepala pemerintahan yang } \\
\text { sah }\end{array}$ & 0 & 0,00 & 1 & 1,12 & 88 & 98,87 \\
\hline
\end{tabular}

Dari tabel di atas dapat kita ketahui bahwa sikap religious-nasionalis telah terbentuk. Siswa SMP Darul Faqih Indonesia sebanyak 98,87\% tidak mempermasalahkan sistem demokrasi yang berlaku di Indonesia dan mendukung setiap kepala pemerintahan yang sah. Hal ini juga dikuatkan dengan $97,75 \%$ siswa memiliki sikap setia terhadap Pancasila, UUD Negara Republik Indonesia Tahun 1945, Bhinneka Tunggal Ika dan Negara Kesatuan Republik Indonesia. Namun, perlu menjadi catatan Bersama, bahwa terdapat $2,24 \%$ siswa yang masih ragu-ragu dengan sikap tersebut. Hal ini menandakan adanya PR besar bagi guru dan tenaga kependidikan untuk memberikan edukasi yang lebih baik tentang sikap kebangsaan mereka.

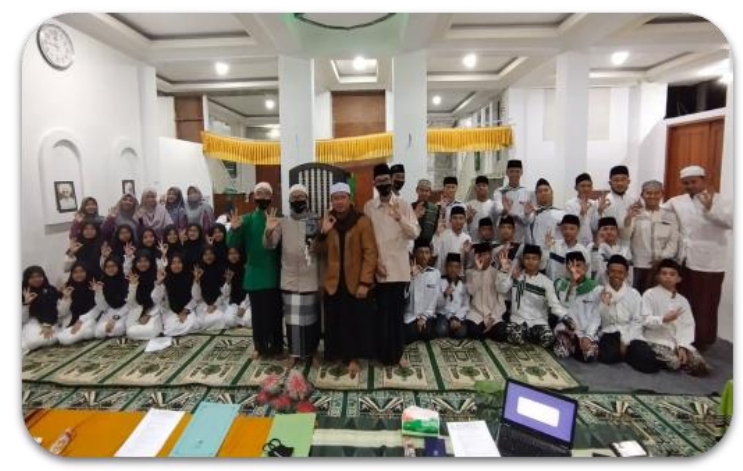

Gambar 4. Pendampingan materi Aswaja oleh tim pengabdian

Di sisi lain, sikap siswa dalam mengimplementasikan Aswaja dalam kegiatan sehari-hari dapat tercermin dari respon siswa terhadap mengamalkan amaliyah Aswaja An-Nahdliyah sebesar 92,13\%. Toleransi beragama yang ditunjukkan juga memiliki cerminan skor yang besar yakni $94,38 \%$. Hal ini menunjukkan adanya karakter religious-nasionalis dalam diri siswa. 
Pada fase kedua, tim pengabdian melakukan diskusi penguatan materi nasionalisme dan semangat kebangsaan yang bekerjasama dengan UPT Pusat Pengkajian Pancasila Universitas Negeri Malang. Penguatan materi kebangsaan ini diperlukan untuk mengintegrasikan mata pelajaran Pendidikan Pancasila dan Kewarganegaraan (PPKn) dengan Pendidikan Agama Islam (PAI) sebagai muatan pendidikan karakter di sekolah.

Adapun dalam praktik keseharian muslim berkarakter Aswaja religiousnasionalis dapat dilihat dari data di bawah ini yang menunjukkan respon siswa terhadap praktik penyelenggaraan ajaran Aswaja.

Tabel 2. Hasil respon praktik santri terhadap model pembelajaran Aswaja $(n=10)$

\begin{tabular}{|c|c|c|c|c|c|c|c|}
\hline \multirow{2}{*}{ No. } & \multirow{2}{*}{ Pernyataan } & \multicolumn{2}{|c|}{$\begin{array}{c}\text { Tidak } \\
\text { Pernah }\end{array}$} & \multicolumn{2}{|c|}{$\begin{array}{l}\text { Kadang- } \\
\text { Kadang }\end{array}$} & \multicolumn{2}{|c|}{ Selalu } \\
\hline & & $\begin{array}{c}\text { Freq } \\
(n)\end{array}$ & $\%$ & $\begin{array}{c}\text { Freq } \\
(n)\end{array}$ & $\%$ & $\begin{array}{c}\text { Freq } \\
(n)\end{array}$ & $\%$ \\
\hline $\mathrm{P} 1$ & $\begin{array}{l}\text { Menjaga keberagaman dalam beragama dan } \\
\text { berbudaya sebagai pengamalan paham } \\
\text { Aswaja an-Nahdliyah }\end{array}$ & 1 & 1,13 & 2 & 2,24 & 86 & 96,62 \\
\hline $\mathrm{P} 2$ & $\begin{array}{l}\text { Bersikap moderat dan toleran terhadap } \\
\text { berbagai aspek kehidupan dan menolak paham } \\
\text { liberal }\end{array}$ & 0 & 0,00 & 2 & 2,24 & 87 & 97,75 \\
\hline P3 & $\begin{array}{l}\text { Melaksanakan tradisi Islami yang berlaku di } \\
\text { tengah masyarakat seperti tahlilan, manaqiban, } \\
\text { maulidan, dan kegiatan lain yang tidak } \\
\text { bertentangan dengan ajaran Islam }\end{array}$ & 0 & 0,00 & 3 & 3,37 & 86 & 96,62 \\
\hline $\mathrm{P} 4$ & $\begin{array}{l}\text { Bersikap loyal terhadap pemerintahan yang } \\
\text { sah sebagai pengamalan ajaran Aswaja an- } \\
\text { Nahdliyah }\end{array}$ & 0 & 0,00 & 1 & 1,13 & 88 & 98.87 \\
\hline P5 & $\begin{array}{l}\text { Menganggap bahwa NKRI adalah } \\
\text { pemerintahan yang sah menurut Islam }\end{array}$ & 0 & 0,00 & 2 & 2,24 & 87 & 97,75 \\
\hline P6 & $\begin{array}{l}\text { Berperan aktif dalam mengawal moderatisme } \\
\text { Islam di Indonesia }\end{array}$ & 1 & 1,13 & 2 & 2,24 & 86 & 96,62 \\
\hline P7 & $\begin{array}{l}\text { Senantiasa mengedepankan musyawarah } \\
\text { keilmuan dalam menyelesaikan permasalahan } \\
\text { masyarakat }\end{array}$ & 1 & 1,13 & 3 & 3,37 & 85 & 95,50 \\
\hline P8 & $\begin{array}{l}\text { Menganggap tradisi ajaran Aswaja an- } \\
\text { Nahdliyah yang telah ada di masyarakat } \\
\text { Indonesia telah sesuai dengan ajaran Islam }\end{array}$ & 1 & 1,13 & 2 & 2,24 & 86 & 96,62 \\
\hline P9 & $\begin{array}{l}\text { Berperan aktif dalam menjaga dan } \\
\text { melestarikan kearifan lokal dan kebudayaan } \\
\text { asli daerah yang tidak bertentangan dengan } \\
\text { ajaran Islam }\end{array}$ & 0 & 0,00 & 1 & 1,13 & 88 & 98,87 \\
\hline P10 & $\begin{array}{l}\text { Menempatkan Pancasila sebagai ideologi } \\
\text { bangsa dan tidak bertentangan dengan } \\
\text { semangat ajaran Islam Aswaja an-Nahdliyah }\end{array}$ & 0 & 0,00 & 1 & 1,13 & 88 & 98,87 \\
\hline
\end{tabular}

Berdasarkan hasil penilaian sikap dan praktik muslim Aswaja ini dapat ditarik sebuah korelasi atau hubungan antar variable. Berikut merupakan tabel korelasi antara skor sikap dan praktik siswa.

Tabel 3. Korelasi skor sikap dan praktik

\begin{tabular}{ccc}
\hline \multirow{2}{*}{ Variable } & \multicolumn{2}{c}{ Correlation } \\
\cline { 2 - 3 } & R Square & $\boldsymbol{p}$-Value \\
\hline Sikap - Praktik & 0.126 & 0.000 \\
\hline
\end{tabular}




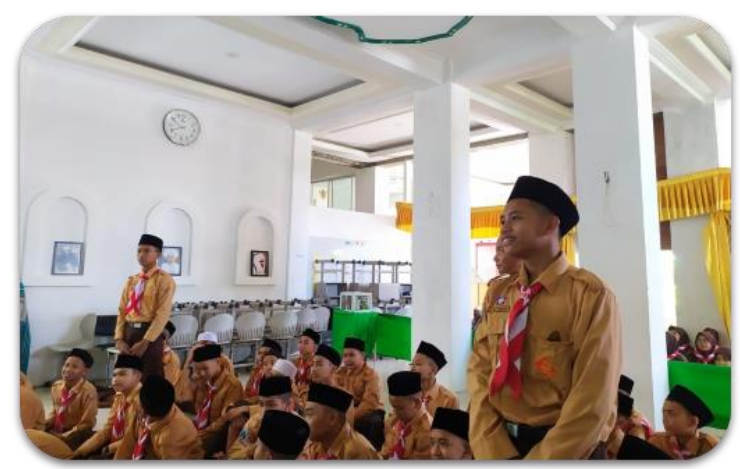

Gambar 5. Keaktifan peserta dalam mengikuti rangkaian kegiatan

Pada fase ketiga, setelah melakukan dua proses edukasi mendalam kepada siswa, tim pengabdian masyarakat melakukan pembinaan, pengawasan dan pendampingan secara berkala selama 3 bulan sejak bulan Maret hingga Mei 2021. Kegiatan ini dilakukan untuk memastikan bahwa internalisasi nilai-nilai religious-nasionalis benar-benar berjalan dengan baik di lingkungan sekolah. Tim meyakini bahwa pembentukan karakter siswa tidak bisa dilaksanakan dalam satu atau dua kali pertemuan, namun membutuhkan pembiasaan dalam jangka waktu yang relatif lama. Pembinaan dan pendampingan ini melibatkan berbagai unsur diantaranya kepala sekolah, wakil kepala sekolah bidang kesiswaan, guru mata pelajaran PPKn dan PAl serta siswa sebagai mitra pengabdian. Berdasarkan uraian hasil di atas, dapat ditarik sebuah persepsi bahwa setiap siswa yang mengikuti kegiatan edukasi telah mampu menampilkan sikap karakter religious-nasionalis melalui implementasi model pembelajaran Aswaja di sekolah.

\section{KESIMPULAN}

Karakter menandai sebuah ciri khas manusia satu dengan lainnya. Islam merupakan agama yang menjunjung tinggi nilai kemanusiaan dan kesetaraan. Dari data di atas, pengabdian kepada masyarakat ini dapat disimpulkan bahwa (1) terjadi peningkatan pemahaman yang signifikan yang ditunjukkan dengan besarnya perolehan skor sikap dan praktik dalam pembelajaran Aswaja; (2) siswa telah mampu menunjukkan sikap positif terhadap nilai-nilai kebangsaan dan keislaman dengan semangat moderasi beragama; (3) penanaman nilainilai religious-nasionalis diperlukan mengingat masih adanya beberapa siswa yang ragu-ragu terhadap sikap kebangsaan dan keislaman yang moderat.

Untuk mencapai luaran hasil pengabdian yang mampu memberikan dampak nyata kepada masyarakat diperlukan beberapa hal berikut sebagai refleksi atas pelaksanaan kegiatan ini diantaranya: (1) diperlukan koordinasi terstruktur terhadap berbagai pihak yang terlibat agar kegiatan berjalan dengan lancer; (2) Di tengah pandemi Covid-19, kegiatan pengabdian kepada masyarakat perlu dilakukan secara inovatif, kreatif dan dapat menggunakan berbagai platform digital; (3) Pemilihan sasaran pengabdian benar-benar didasarkan oleh analisis kebutuhan dan masalah yang terjadi di lapangan. 
Kegiatan pengabdian kepada masyarakat ini setidaknya telah mampu memberikan kontribusi nyata dalam membentuk muslim berkarakter nasionalisreligius.

\section{UCAPAN TERIMA KASIH}

Ucapan terimakasih kami sampaikan kepada LP2M Universitas Negeri Malang yang telah memberikan dana PNBP UM tahun anggaran 2021 sebagai bentuk dukungan kegiatan pengabdian. Kami juga menyampaikan ucapan terimakasih kepada SMP Darul Faqih Indonesia yang bertindak sebagai mitra dalam program kemitraan masyarakat ini.

\section{DAFTAR RUJUKAN}

Abdullah, M. H., \& Yani, M. T. (2009). Wacana Islam Inklusif dalam Kuliah Pendidikan Agama Islam di Perguruan Tinggi Umum. Jurnal Nadwa IAIN Walisongo, 3(1). https://doi.org/10.21580/nw.2021.1.1.7513

Al-Zewairi, M., \& Naymat, G. (2017). Spotting the Islamist Radical within: Religious Extremists Profiling in the United State. Procedia Computer Science, 113, 162-169. https://doi.org/10.1016/j.procs.2017.08.336

Aspihanto, A., \& Muin, F. (2017). Sinergi Terhadap Pencegahan Terorisme dan Paham Radikalisme. Seminar Nasional Hukum Universitas Negeri Semarang, 3(1), 73-90.

Hanafi, Y., \& Ikhsan, M. A. (2019). Prosecuting The House of God: The Irony of Rights to Freedom of Worship for Dhimmi Minority in Indonesia. Justicia Islamica, 16(1), 1-20. https://doi.org/10.21154/justicia.v16i1.1535

Ibrahim, I., Wulansari, D., \& Hidayat, N. (2017). Radicalism in Indonesia and the Reflective Alternatives to Reduce. PEOPLE: International Journal of Social Sciences, 3(3), 1554-1564. https://doi.org/DOIhttps://dx.doi.org/10.20319/pijss.2018.33.15541564

Ikhsan, M. A. (2017a). Fikih HAM dan Hak Kebebasan Beribadah Minoritas Dzimmi di Indonesia. Jurnal Ilmiah Pendidikan Pancasila dan Kewarganegaraan, 2(1), 34-40. http://dx.doi.org/10.17977/um019v2i12017p034

Ikhsan, M. A. (2017b). Nilai-Nilai Cinta Tanah Air dalam Perspektif Al-Quran. Jurnal Ilmiah Pendidikan Pancasila dan Kewarganegaraan, 2(2), 108114. http://dx.doi.org/10.17977/um019v2i22017p108

Ikhsan, M. A. (2019). Al-Quran Dan Deradikalisasi Paham Keagamaan Di Perguruan Tinggi: Pengarusutamaan Islam Wasathiyah. Al-Bayan: Jurnal IImu al-Qur'an Dan Hadist, 2(2), 98-112. https://doi.org/10.35132/albayan.v2i2.71

Labiba, S. (2021). Pembelajaran Aswaja untuk Menangkal Paham Radikalisme Intoleran pada Peserta Didik di MA Maarif Al-Asy'ari Ranggeh Pasuruan. Turatsuna : Jurnal Keislaman Dan Pendidikan, 3(1), 122-138.

Llorent-Bedmar, V., Cobano-Delgado Palma, V. C., \& Navarro-Granados, M. (2020). Islamic religion teacher training in Spain: Implications for preventing islamic-inspired violent radicalism. Teaching and Teacher Education, 95, 103138. https://doi.org/10.1016/j.tate.2020.103138 
Maskuri, M., Ma'arif, A. S., \& Fanan, M. A. (2020). Mengembangkan Moderasi Beragama Mahasantri Melalui Ta'lim Ma'hadi di Pesantren Mahasiswa. J-PAl: Jurnal Pendidikan Agama Islam, 7(1), Article 1. https://doi.org/10.18860/jpai.v7i1.11239

Patriadi, H. B. (2015). Human Security in Local Wisdom Perspective: Pesantren and its Responsibility to Protect People. Procedia Environmental Sciences, 28, 100-105. https://doi.org/10.1016/j.proenv.2015.07.015

Rahardjo, T. (2017, July 18). Radikalisme di Kalangan Mahasiswa sudah Mengkhawatirkan. Lembaga IImu Pengetahuan Indonesia (LIPI). http://lipi.go.id/berita/single/RADIKALISME-DI-KALANGANMAHASISWA-SUDAH-MENGKHAWATIRKAN/18630

Rifa'i, A., Prajanti, S. D. W., \& Alimi, M. Y. (2017). Pembentukan Karakter Nasionalisme melalui Pembelajaran Pendidikan Aswaja pada Siswa Madrasah Aliyah Al Asror Semarang. Journal of Educational Social Studies, 6(1), 7-19. https://doi.org/10.15294/jess.v6i1.16250

Saefudin, A., \& Fatihah, A. F. A. (2020). Islamic Moderation Through Education Characters of Aswaja An-Nahdliyyah. Nazhruna: Jurnal Pendidikan Islam, 3(2), 160-179. https://doi.org/10.31538/nzh.v3i2.594

Saleh, M. N. I., Nudin, B., Khusaini, K., Alim, P., \& Putri, I. A. (2019). Islamic Boarding School and the Deradicalization Efforts of Islamic Education in Madura. Jurnal Pendidikan Islam, 8(2), 259-286. https://doi.org/10.14421/jpi.2019.82.259-286

Syarif, N. (2021, February 9). Aswaja (Ahl Sunnah Wal Jamaah), NU dan Negara Islam. http://digilib.uinsgd.ac.id/36914/

UNESCO. (1995). Declaration of Principles on Tolerance. http://www.refworld.org/docid/ 453395954.html

Wahyudin, D. (2017). Pendidikan Aswaja sebagai Upaya Menangkal Radikalisme. Dinamika Penelitian: Media Komunikasi Sosial, 17(2 Tahun 2017). tulungagung.ac.id/index.php/dinamika/article/view/841

Yaqin, A., Rozi, S., \& Sham, F. M. (2020). The Paradox of Pesantren Education in the Implementation of Islamic Law: Study of Pesantren Kyai Notion in Mojokerto. Jurnal Pendidikan Islam, 9(1), 129-148. https://doi.org/10.14421/jpi.2020.91.129-148

Yeşilova, H. (2010). Justice, Human Rights, and the Quasi-Civil Society in a Muslim Context. European Journal of Economic and Political Studies, 3(2), 127-144. 